\title{
IMPLEMENTASI PELAKSANAAN LAYANAN PENEMPATAN DAN PENYALURAN SMA NEGERI 2 TARAKAN TAHUN AJARAN 2017-2018
}

\author{
Faris, Hendra Pribadi, Hendra Pribadi \\ Fakultas Keguruan dan Ilmu Pendidikan, Universitas Borneo Tarakan \\ farisris1010@gmail.com
}

\begin{abstract}
This Research was to find out how the implementation of placement and the distribution of SMA Negeri 2 Tarakan year 2017-2018. Explain how the implementation of placement and distribution services. This study was conducted with a subject of counseling teacher. The techniques of collecting data were conducted in-depth interviews, observation and documentation. Data analysis techniques Were data reduction, data display, and conclusion. Then analyzed by using technique of data validity.

The results showed that the implementation of placement service and distribution of SMA Negeri 2 Tarakan Year Teaching Year 2017/2018 implemented in accordance with the program that has been made.
\end{abstract}

Keywords: Implementation of Placement service and Distributio

\section{PENDAHULUAN}

Menurut Prayitno dan Erman Amti (2004) hakikat manusia sebagai makhluk paling indah dan paling tinggi derajat mendorong manusia untuk maju dan berkembang tanpa henti. Dengan predikat tersebut manusia menjalani kehidupan, karena manusia dikaruniai kemampuan dengan derajat yang paling tinggi itu, maka kesenangan dan malapetaka berada ditangan manusia. Manusia yang menentukan nasib sendiri, hidup kesenangan atau dengan malapetaka.

Dalam hubungan inilah, bimbingan dan konseling mempunyai peran yang penting dalam pendidikan, yakni membantu siswa agar berkembang secara optimal. Dengan demikian, hasil pendidikan akan tercermin pada siswa yang berkembang baik akademik, psikologis, social. The American Psychological Association, Divison of Counseling Psychology, Committee on Defination (1956), mendefinisikan konseling sebagai proses membantu individu mengatasi masalah dalam perkembangan dan memantau mencapai perkembangan optimal.

\section{The American Psychological}

Assocation bahwa konseling berfokus pada pengalaman, perasaan, tingkah laku untuk tujuan personal. Hal ini konseling memberikan kesempatan kepada individu untuk mengeksplorasi dan mengekspresikan ide, perasaan dalam lingkungan yang tidak menilai dan mengancam. Pada dasarnya, konseling sudah menjadi bagian penting di dunia pendidikan.

Bimbingan konseling menjadi bagian yang tidak dipisahkan dalam sekolah. Keberadaan bimbingan konseling dimana memberikan pelayanan mengembangkan pribadi, kehidupan sosial serta pengembangan karier siswa di sekolah. Oleh karena itu bimbingan dan konseling menempati posisi strategis dalam pengembangan diri siswa. 
Dari uraian di atas, bahwa bimbingan konseling merupakan bagian integral dari program pendidikan. Layanan penempatan dan penyaluran siswa dalam memperoleh bimbingan yang tepat di dalam kelas, kelompok belajar, jurusan/program studi, program latihan, magang, dan kegiatan ekstra kurikuler.

Saat ini SMA Negeri 2 Tarakan mengemban visi dan misi sebagai lembaga pendidikan yang mampu bersaing dengan lembaga pendidikan menengah atas yang lain. Sebagai sekolah yang mempunyai sikap peduli terhadap pengembangan diri dan potensi siswa, SMA Negeri 2 Tarakan bertujuan mewujudkan sekolah unggul yang mampu mencetak siswa yang mandiri di dalam pengembangan karirnya. Dalam hal ini sikap kemandirian siswa SMA Negeri 2 Tarakan adalah kemandirian dalam memilih jurusan yang sesuai dengan minat, bakat, dan kemampuannya yang dimiliki serta potensi yang ada pada diri siswa tersebut.

Melihat bagaimana penting- nya bimbingan dan konseling dalam dunia pendidikan, maka yang kita lihat dalam realitasnya masih banyak sekolah tidak mengoptimalkan atau tidak memiliki program terkait bimbingan dan konseling, maka tidak heran ketika siswa tamat dari sekolah, mereka ragu dalam menjalani kehidupannya. Tentu potensi atau bakat yang ada dalam dirinya tidak berjalan optimal selama masih dididik sekolah. Hal seperti ini merupakan masalah teknis, misalnya guru BK yang kurang berkompenten dalam bidang tersebut.

Saat siswa telah lulus sekolah siswa tidak dapat menentukan arah masa depan,seperti tidak melanjutkan kejenjang lebih tinggi, salah memilih jurusan yang tidak sesuai minat dan bakatnya. Oleh sebab itu, layanan bimbingan konseling dibutuhkan di sekolah. Layanan Penempatan dan Penyaluran Bimbingan Konseling diharapkan mampu menyalurkan bakat dan minat. Oleh karena itu layanan penempatan dan penyaluran diharapakan mampu memberikan kesempatan kepada siswa dalam mengembangkan potensi diri.

Berdasarkan latar belakang di atas, layanan penempatan dan penyaluran bimbingan konseling yang sudah berjalan di SMA Negeri 2 Tarakan diorientasikan untuk menuntaskan kesulitan siswa dalam pengembangan diri siswa, sehingga dengan kerangka implementasi aplikatif tersebut dapat memberikan alternatif positif bagi siswa dalam menatap dan merencanakan masa depannya. Dengan demikian, maka penulis berinisiatif untuk melakukan penelitian dengan judul "Implementasi Pelaksanaan Layanan Penempatan dan

Penyaluran di SMA Negeri 2 Tarakan".

\section{METODE PENELITIAN}

Pendekatan yang digunakan dalam penelitian ini adalah menggunakan jenis penelitian deskriptif kualitatif. Penelitian kualitatif merupakan pengamatan kualitatif yang dipertentangkan dengan pengamatan kuantatif. David Williams (1995) menjelaskan penelitian kualitatif adalah pengumulan data pada suatu latar alamiah, dengan menggunakan metode alamiah. Sedangkan Denzin dan Lincoln (1987) menyatakan bahwa penlitian kualitatif adalah penelitian yang menggunakan latar alamiah dengan maksud menasirkan fenomena yang terjadi dan dilakukan dengan berbagai metode.

\section{Subjek Penelitian}


Dalam penelitian yang berjudul Implementasi pelaksanaan Layanan Penempatan dan Penyaluran Terhadap Kegiatan Bimbingan Konseling SMA Negeri 2 Tarakan Tahun Pelajaran 2016/2017 yang akan menjadi subjek penelitannya adalah guru Bimbingan Konseling sekolah SMA Negeri 2 Tarakan. Dimana penelitian ini akan menjelaskan bagaimana pelaksanaan Layanan Penempatan dan Penyaluran kegiatan Bimbingan Konseling di sekolah SMA Negeri 2 Tarakan. Subjek diperoleh satu guru BK (DR) melalui wawancara dan dokumentasi.

\section{Data dan Sumber Data}

Penelitian akan memperoleh sumber data, baik sumber data yang digunakan dapat memberikan data yang dapat dipertanggung jawabkan kebenarannya dan kemudian data yang dikumpulkan dalam penelitian ini berbentuk data kualitatif yaitu wawancara, dokumentasi atau literaturliteratur yang berkaitan judul penelitian peneliti. Adapun sumber data yang akan diperoleh dalam penelitian ini adalah:

1. Sumber data primer yaitu subjek itu sendiri (guru Bimbingan Konseling). Data tersebut untuk mengetahui pelaksanaan Layanan penempatan dan penyaluran SMA Negeri 2 Tarakan dengan data diperoleh melalui wawancara.

a. Guru BK DR untuk melaksanakan layanan penempatan dan penyaluran seperti penempatan di dalam kelas, penempatan dan penyaluran ke dalam kelompok belajar, penempatan dan penyaluran kedalam kegiatan ekstrakurikuler, penempatan dan penyaluran kedalam pendidikan lanjutran dan penempatan dan penyaluran ke jurusan/program studi;

b. Wali kelas untuk pelaksanaan layanan penempatan dan penyaluran guru wali kelas bekerjasa sama utnuk mendampingi siswa seperti penempatan di dalam kelas guru wali kelas membantu guru BK untuk menentukan tempat duduk yang berdasarkan kebutuhan siswa;

c. Pembina ekstrakurikuler umtuk pelaksanan layanan penempatan dan penyaluran kegiatan ekstrakurikuler guru BK bekerjasa sama dengan pembina untuk mempromosikan kepada setiap kelas agar membantu siswa mengembangkan bakat minta sesuai dengan potensi;

d. Siswa untuk pelaksanaan layanan penempatan dan penyaluran yang dilakukan oleh guru BK, seperti penempatan dan penyaluran kedalam kelas yang dilakukan setiap awal tahun pelajaran, penempatan dan penyaluran kedalam kedalam kelompok belajar seperti mendampingi proses belajar kelompok, penempatan dan penyaluran ke dalam kegiatan ekstrakurikuler guru BK dan pembina ekskul mempromosikan dan mendampingi siswa, penempatan dan penyaluran kedalam pendidikan lanjutan guru BK memberikan layanan informasi mengenai IPDN, dan universitas, penempatan dan penyaluran ke dalam jurusan./program studi guru BK memberikan angket peminatan jurusan .

2. Sumber Data Sekunder ialah data pendukung data primer berupa dokumen, litaratur, foto dokumentasi serta informasiinformasi yang relavan dengan penelitian peneliti.

\section{Teknik Pengumpulan Data}

Setelah data-data penelitian ini diketahui sumbernya, maka langkah selanjutnya adalah pengumpulan data. Teknik pengumpulan data dalan penelitian kualitatif tentu berkaitan dengan jenis penelitian kualitatif ini yang merupakan penelitian lapangan dalam menyelidiki suatu fenomena sosial dan masalah sosial. Oleh karena itu adapun 
teknik yang akan digunakan dalam penelitian ini adalah dengan menggunakan wawancara mendalam. Fungsi wawancara disini untuk mengetahui pelaksanaan layanan penempatan dan penyaluran bimbingan konseling di Sekolah SMA Negeri 2 Tarakan.

\section{Teknik Analisis Data}

Setelah data terkumpul, selanjutnya diadakan analisis data. Analisis data menurut Moleong (2014) adalah suatu proses pengorganisasian serta mengurutkan data ke dalam pola, kategori, dan satuan uraian dasar sehingga dapat ditemukan tema dan dirumuskan hipotesis kerja seperti yang ada pada data. Jenis analisis data yang digunakan adalah kualitatif deskriptif. Analisis tersebut merupakan proses menganalisis data secara sistematis berdasaran temuan yang diperoleh melalui wawancara dan observasi dalam bentuk deskripsi, yaitu penggambaran hasil penelitian melalui penjelasanpenjelasan yang menunjukkan tentang bagaimana Layanan Penempatan dan Penyaluran Bimbingan Konseling di Sekolah SMA Negeri 2 Tarakan. Analisis data kualitatif, terdiri dari tiga jalur kegiatan yang terjadi secara bersamaan, yaitu reduksi data, penyajian data, dan penarikan kesimpulan atau vertifikasi.

a. Reduksi data, adalah pemusatan perhatian pada penyederhanaan, pengabstrakan, dan transformasi data dan dasar yang muncul dari catatan-catatan tertulis di lapangan. Reduksi data merupakan suatu bentuk analisis yang menjamakan, menggolongkan, mengarahkan, mengorganisasikannya, sehingga data siap disajikan dan dapat ditarik kesimpulannya dan selanjutnya diverifikasi.

b. Penyajian data, setelah data yang disajikan dalam bentuk sekumpulan informasi dari sumber dan metode. Selanjutnya data yang tersusun dimungkinkan untuuk dianalisis dan ditarik kesimpulan sebagai langkah verifikasi.

c. Penarikan kesimpulan atau verifikasi, adalah sebagian dari suatu kegiatan konfigurasi yang utuh. Di dalam menarik kesimpulan harus diverifikasi, makna-makna yang muncul dari data yang harus di uji kebenarannya, kekokohonnya, dan kecocokannya agar dapat diperoleh data yang valid.

\section{HASIL DAN PEMBAHASAN}

Pernyataan dari guru BK (DR) bahwa pelaksanaan layanan penempatan dan penyaluran di SMA Negeri 2 Tarakan terlaksana dengan maksimal. Guru BK melaksanakan program layanan sesuai dengan program yang ada, dan mengikuti kurikulum yang berlaku, sedangkan guru BK SMA Negeri 2 DR melaksanakan layanan penempatan dan penyaluran dengan "versinya sendiri". Pemahaman DR bahwa setiap guru BK di sekolah manapun mempunyai tujuan yang sama yaitu upaya guru BK untuk meminimalisir permasalahan siswa.

Secara struktur dan administrasi, bimbingan dan konseling di SMA Negeri 2 Tarakan dapat dikatakan cukup baik. Hal ini dapat dilihat dari personil yang berperan dalam pelayanan bimbingan dan konseling. Secara umum personil yang terlibat yaitu personil pada kantor dinas pendidikan yang bertugas melakukan pengawasan dan pembinaan terhadap penyelenggaraan layanan bimbingan dan konseling, kepala sekolah sebagai penanggung jawab, guru BK sebagai tenaga inti dalam pelaksanaan bimbingan dan konseling, wali kelas dan guru-guru mata pelajaran sebagai tenaga ahli dalam mata pelajaran, orang tua sebagai penanggung jawab utama siswa, dan sesama siswa sebagai sasaran bimbingan dan konseling. Keterlibatan dan kerjasama seluruh personil ini tidak sepenuh berjalan dengan maksimal di 
SMA Negeri 2 Tarakan, namun jika dinilai dari struktur bimbingan konseling, maka dapat dikategorikan cukup baik, seperti diuraikan dalam buku Implementasi Bimbingan dan Konseling di Sekolah (Wardati, dkk 2011).

Pelaksanaan layanan penempatan dan penyaluran di SMA Negeri 2 Tarakan sudah maksimal terlihat seperti pada pelaksanaan layanan penempatan dan penyaluran didalam kelas berjalan cukup baik. Kalau dilihat secara umum pada awal tahun ajaran baru setiap guru wali kelas dengan guru BK bekerja sama untuk menentukan tempat duduk siswa berdasarkan secara jenis kelamin siswa yang ada. Biasanya siswa putri tidak mau duduk sebangku dengan siswa putra. Untuk layanan penempatan dan penyaluran didalam kelas biasanya ada siswa yang menghadap kewali kelas atau guru BK untuk meminta tempat secara khusus seperti siswa yang minus (rabun jauh maupun dekat).

Kemudian untuk layanan penempatan dan penyaluran kedalam kelompok belajar kurang berjalan dengan maksimal disekolah hanya saja beberapa kelompok atau siswa seperti jurusan ipa mereka lebih banyak masuk kedalam kelompok ekstrakurikuler Kegiatan Ilmiah Remaja (KIR) memang untuk penempatan kelompok belajar disekolah kurang muncul, ada inisiatif siswa sendiri yang datang keruangan BK untuk melakukan konseling individu ataupun kelompok.

Untuk layanan penempatan dan penyaluran ke dalam kegiatan ektrakurikuler sekolah sangat peduli dengan pengembangan potensi siswa dimana salah satu syarat daftar masuk kesekolah SMA Negeri 2 Tarakan melampirkan sertifikat yang dimiliki siswa agar kedepanya siswa lerbih mudah untuk diarahkan. Untuk pemilihan ekstrakurikuler guru BK bekerjasama dengan pembina ekstrakurikuler setiap pembina masuk kekelas mempromosikan ekskurikuler agar dapat menyalurkan bakat dan mintanya siswa secara optimal. Untuk siswa yang memiliki prestasi non akademik sekolah minta kepada setiap guru bidang studi untuk melakukan pengecualian seperti ketika membawa nama baik sekolah pada saat ulangan harian siswa tersebut bisa mengikuti seusai melakukan kegitannya dengan catatan mengejar ketertinggalanya dengan guru bidang studi tersebut.

Penempatan dan penyaluran ke dalam Pendidikan Lanjutan biasanya siswa sendiri yang mendatangi guru BK keruang BK . sebelum siswa itu datang keguru BK biasanya siswa sudah mendapatkan informasi secara pribadi. Layanan penempatan dan penyaluran pendidikan lanjutan guru BK bekerja sama dengan pihak sekolah agar terbuka dengan pihak perguruan tinggi ataupun institusi seperti polisi tentara IPDN agar dapat memberikan informasi dan gambaran secara langsung. Setiap tahun sekolah SMA Negeri 2 Tarakan kedatangan tamu seperti Polisi, tentara maupun IPDN, Penempatan dan penyaluran ke dalam Pendidikan Lanjutan sudah menjadi agenda tahuan untuk memberikan informasi kepada siswa

Untuk layanan penempatan dan penyaluran kejurusan atau program studi ada rumus nilai secara nilai berupa angka mata pelajaran apa. Pendaftaran awal masuk kelompok peminatan pada saat di terima . Untuk peminatan juga sudah diatur oleh guru BK berdasarkan angket dan nilai raport sebelumnya untuk peminatan kelas 11 akan dilihat dari hasil raport kelas 10 untuk peminatan kelas IPA, IPS atau BAHASA. Untuk melihat kesesuain antara potensi dan kondisi siwa guru BK juga melakukan kerja sama dengan wali kelas untuk mengetahui permasalahan pada siswa untuk menghindari salah pemilihan jurusan dengan melakukan pemantauan selama satu semester. SMA Negeri 2 tarakan juga memiliki program lintas minat yang dimana setiap jurusan wajib memilih mata pelajaran tambahan yang bukan 
sesuai dengan jurusan mereka untuk bisa mempelajari jurusan lain.

Fungsi yang hendak dipenuhi melalui pelaksanaan layanan penempatan dan penyaluran yaitu fungsi pemahaman, fungsi pencegahan, fungsi pengentasan, fungsi pengembangan dan pemeliharahan. Secara tidak langsung fungsi-fungsi ini telah terlaksana ketika siswa menerima sosialisasi dari instansi-instansi yang dimana telah difasilitasi oleh humas yang juga merupakan guru BK (Wardati, dkk 2011).

\section{KESIMPULAN}

Berdasarkan pembahasan yang telah dikemukakan pada bab IV, maka peneliti dapat menarik kesimpulan sebagai berikut :

Pelaksanaan layanan penempatan dan penyaluran di SMA Negeri 2 Tarakan berjalan sesuai dengan program yang telah dibuat oleh guru BK, dalam pelaksanaan layanan penempatan dan penyaluran guru BK bekerjasama dengan guru wali kelas, pembina ektrakurikuler dan siswa.

Seperti penampatan dan penyaluran didalam kelas sudah terlaksana terlihat dari guru BK bekerja sama dengan wali kelas untuk menentukan tempat duduk berdasarkan kebutuhan siswa meskipun dalam pelaksanaanya setahun sekali. Penempatan dan penyaluran ke dalam kelompok belajar terlaksana terlihat dari guru BK melakukan pendampingan kelompok belajar seperti jurusan IPA, IPS, maupun Bahasa. Penempatan dan penyaluran kedalam kegiatan ektrakurikuler terlaksana terlihat dari guru BK bekerjasama dengan pembina ekskul untuk mempromosikan dan mendampingi siswa dalam pengembangan minat bakat. Penempatan dan penyaluran kedalam pendidikan lanjutan terlaksana terlihat adanya kerjasama antara sekolah dan institusi seperti, IPDN, Polisi, dan Universitas untuk melaksanakan sosialisasi langsung kepada siswa. Penempatan dan penyaluran ke jurusan/program studi terlaksana terlihat dari guru BK memberikan angket pemintan kepada siswa dan juga melakukan pendampingan kepada siswa utnuk menghindari salah pilih jurusan.

\section{Saran}

1. Bagi Pihak Sekolah

a. Kepala Sekolah, secara intensif bekerjasama dengan pihak luar agar dapat memberikan gambaran langsung dari pelaksanaan layanan penempatan dan penyaluran.

b. Guru, hendaknya guru-guru dan pembina ekstrakurikuler di sekolah secara intensif bekerjasama dengan guru BK sehingga pelaksanaan layanan penempatan dan penyaluran disekolah dapat terlaksana sesuai dengan yang diinginkan.

c. Konselor atau guru BK, dapat menyusun program sesuai dengan kebutuhan siswa dan melaksanakan program layanan penempatan dan penyaluran secara maksimal 2. Bagi peneliti selanjutnya Diharapkan hasil penelitian ini dijadikan bahan panduan atau referensi untuk mengkaji lebih lanjut mengenai pelaksanaan layanan penempatan dan penyaluran di sekolah, serta dapat menggunakan penelitian ini di sekolah lain

\section{DAFTAR PUSTAKA}

Ahmadi, Rulam. 2014.

Metodologi Penelitian

Kualitatif. Yogyakarta: Ar-

Ruzz Media.

Anisa, Anisa. 2015. Penerapan layanan penempatan dan penyaluran belajar dalam memilih jurusan pada MAN 2 Kandangan. Kandangan: Skripsi Tarbiyah dan Keguruan 
Arikunto, Suharsimi. 2013.

Prosedur Penelitian. Jakarta : Rineka Cipta.

Badan Standar Nasional Pendidikan. 2006. Panduan Pengembangan Diri. Jakarta.

Moleong, Lexy J. 2014. Metodologi Penelitian Kualitatif. Bandung : PT. Remaja Rosdakarya.

Prayitno \& Erman Anti. 2015. Dasar-dasar Bimbingan Dan Konseling. Jakarta : Rineka Cipta.

Rohmah, Alifatur. 2011. Pengaruh layanan penempatan dan penyaluran terhadap pemilihan jurusan siswa di SMA Muhammadiyah 3 Surabaya.Surabaya. Surabaya : UIN Ampel.

Sugiyono. 2015. Metode Penelitian Pendidikan. Bandung : Alfabeta.

Andi Muhammad Rizal Amir, 2017. Kesulitan Belajar (Studi Siswa SDK Frater Don Bosco Kota Tarakan). Skripsi. Fakultas Keguruan dan Ilmu Pendidikan Universitas Borneo Tarakan.

Olivia, 2017. Evaluasi

Pelaksanaan Program Layanan Bimbingan dan Konseling SMA Frater Don Bosco Tarakan Skripsi. Fakultas Keguruan dan Ilmu Pendidikan Universitas Borneo Tarakan.

Sukardi, Dewa Ketut \& Desak P. E Nila Kusumawati. 2008. Proses

Bimbingan dan Konseling di Sekolah. Jakarta : Rineka Cipta

2010. Pengantar Pelaksanaan Program Bimbingan Dan Konseling Di Sekolah. Jakarta : Rhineka Cipta.

Tohirin. 2009. Bimbingan Dan Konseling Di

Sekolah \& Madrasah (Berbasis Integrasi). Jakarta : Rajawali Pers Wardati \& Muhammad Jauhar. 2011. Implementasi Bimbingan dan Konseling Di Sekolah. Jakarta: Prestasi Pustkaraya

Nikmah, N. F. 2014. Faktor-faktor Yang Melatarbelakangi Rendahnya Moivasi Belajar Siswa kelas IX SMP
Negeri 22 Semarang. Skripsi tidak diterbitkan. Semarang: Universitas Negeri Semarang.

Prayitno. 2012. Seri Panduan Layanan Dan Kegiatan Pendukung Koneling. Padang: Universitas Negeri Padang.

Prayitno dan Erman, A. 2013. Dasar-dasar bimbingan \& Konseling. Jakarta: Rineka Cipta.

Saleh, A. 2009. Kreatif Mengajar Dengan Mind Map. Bogor: Regina

Sadirman. 2016. Interaksi dan Motivasi Belajar Mengajar: Jakarta: Raja Grafindo Persada.

Santrock, J. W. 2010. Psikologi Pendidikan. Jakarta: Kencana.

Shoimin, A. 2014. 68 Model Pembelajaran Inovatif dalam Kurikulum 2013. Yogyakarta: ArrRuzz Media.

Swadarma, D. 2014. Penerapan Mind Mapping dalam Kurikulum embelajaran. Jakarta: Elex Media Komputindo.

Sugiyono. 2015. Metode Penelitian Pendidikan. Bandung: Alfabeta.

Romlah, T. 2013. Teori dan Praktek Bimbingan Kelompok. Malang: Universitas Negeri Malang.

Rachmawati, T dan Daryanto. 2015. Teori Belajar dan Proses Pembelajaran yang Mendidik. Malang: Gava Media.

Utvær, B. S. K. and Haugan, G. 2016. The Academic Motivation Scale: Dimensionality, Reliability, and Construct Validity Among Vocational Student. Nordic Journal of Vocational Education and Training. 6(2): 17-45.

Uno, H. B. 2017. Teori Motivasi dan Pengukurannya. Jakarta: Bumi Aksara.

Warseno, A dan Kumorojati. R. 2011. Super Learning. Jogjakarta: Diva Press.

Wati, O. E. 2016. Penggunaan Layanan Bimbingan Kelompok untuk Meningkatkan Motivasi Belajar. Skripsi tidak diterbitkan. 
Bandar Lampung: Universitas

Lampung. 